\title{
Biogeochemical processes and the diversity of Nhecolândia lakes, Brazil
}

\author{
TEODORO I.R. ALMEIDA ${ }^{1}$, MARIA DO CARMO CALIJURI ${ }^{2}$, PATRÍCIA B. FALCO ${ }^{2}$, \\ SIMONE P. CASALI ${ }^{2}$, ELENA KUPRIYANOVA ${ }^{3}$, ANTONIO C. PARANHOS FILHO ${ }^{4}$, \\ JOEL B. SIGOLO ${ }^{1}$ and REGINALDO A. BERTOLO ${ }^{1}$ \\ ${ }^{1}$ Instituto de Geociências, Universidade de São Paulo, Rua do Lago, 562, 05508-080 São Paulo, SP, Brasil \\ ${ }^{2}$ Escola de Engenharia de São Carlos, Universidade de São Paulo, \\ Avenida Trabalhador Sãocarlense, 400, 13566-590 São Carlos, SP, Brasil \\ ${ }^{3}$ Institute of Plant Physiology, Russian Academy of Sciences, Botanicheskaya Street 35, Moscow, 127276, Russia \\ ${ }^{4}$ Centro de Ciências Exatas e Tecnologia, Universidade Federal do Mato Grosso do Sul, Cidade Universitária, \\ Avenida Costa e Silva, 1524, 79000-060 Campo Grande, MS, Brasil \\ Manuscript received on February 17, 2010; accepted for publication on October 5, 2010
}

\begin{abstract}
The Pantanal of Nhecolândia, the world's largest and most diversified field of tropical lakes, comprises approximately 10,000 lakes, which cover an area of $24,000 \mathrm{~km}^{2}$ and vary greatly in salinity, $\mathrm{pH}$, alkalinity, colour, physiography and biological activity. The hyposaline lakes have variable $\mathrm{pHs}$, low alkalinity, macrophytes and low phytoplankton densities. The saline lakes have pHs above 9 or 10, high alkalinity, a high density of phytoplankton and sand beaches. The cause of the diversity of these lakes has been an open question, which we have addressed in our research. Here we propose a hybrid process, both geochemical and biological, as the main cause, including (1) a climate with an important water deficit and poverty in $\mathrm{Ca}^{2+}$ in both superficial and phreatic waters; and (2) an elevation of $\mathrm{pH}$ during cyanobacteria blooms. These two aspects destabilise the general tendency of Earth's surface waters towards a neutral $\mathrm{pH}$. This imbalance results in an increase in the $\mathrm{pH}$ and dissolution of previously precipitated amorphous silica and quartzose sand. During extreme droughts, amorphous silica precipitates in the inter-granular spaces of the lake bottom sediment, increasing the isolation of the lake from the phreatic level. This paper discusses this biogeochemical problem in the light of physicochemical, chemical, altimetric and phytoplankton data.
\end{abstract}

Key words: Pantanal, alkaline lakes, saline lakes, cyanobacteria, alkalinization processes.

\section{INTRODUCTION}

The Pantanal is the largest floodable surface on Earth, covering approximately $200,000 \mathrm{~km}^{2}$ (Fig. 1). It is located in the Pantanal Basin (Almeida 1945), an inland tectonic depression that originated from tectonic interactions between the South American and Nazca Plates during the Late Tertiary (Assumpção 1998, Ussami et al. 1999). This basin has been filled by several alluvial fans, generating quaternary sediments dominated by quartzose sands, with maximum thickness of approximately $550 \mathrm{~m}$ (Assine 2004). The Pantanal is divided

Correspondence to: Teodoro Isnard Ribeiro de Almeida E-mail: talmeida@usp.br into 11 sub-areas based on characteristics of seasonal floods, physiography and ecology (Silva et al. 1998). Two of these areas, Paiaguás and Nhecolândia, occupy almost the entire alluvial fan of the Taquari River, with an area of $54,125 \mathrm{~km}^{2}$. This fan is a complex depositional system with an almost circular form approximately $250 \mathrm{~km}$ in diameter, the largest on the planet (Assine 2004).

Nhecolândia, whose $24,000 \mathrm{~km}^{2}$ area occupies the southern half of the Taquari alluvial fan (Fig. 1), has $200 \mathrm{~m}$ of altitude in the eastern most part and $80 \mathrm{~m}$ near the Paraguay River. This alluvial fan is still active with summer floods. The local annual rainfall is around 


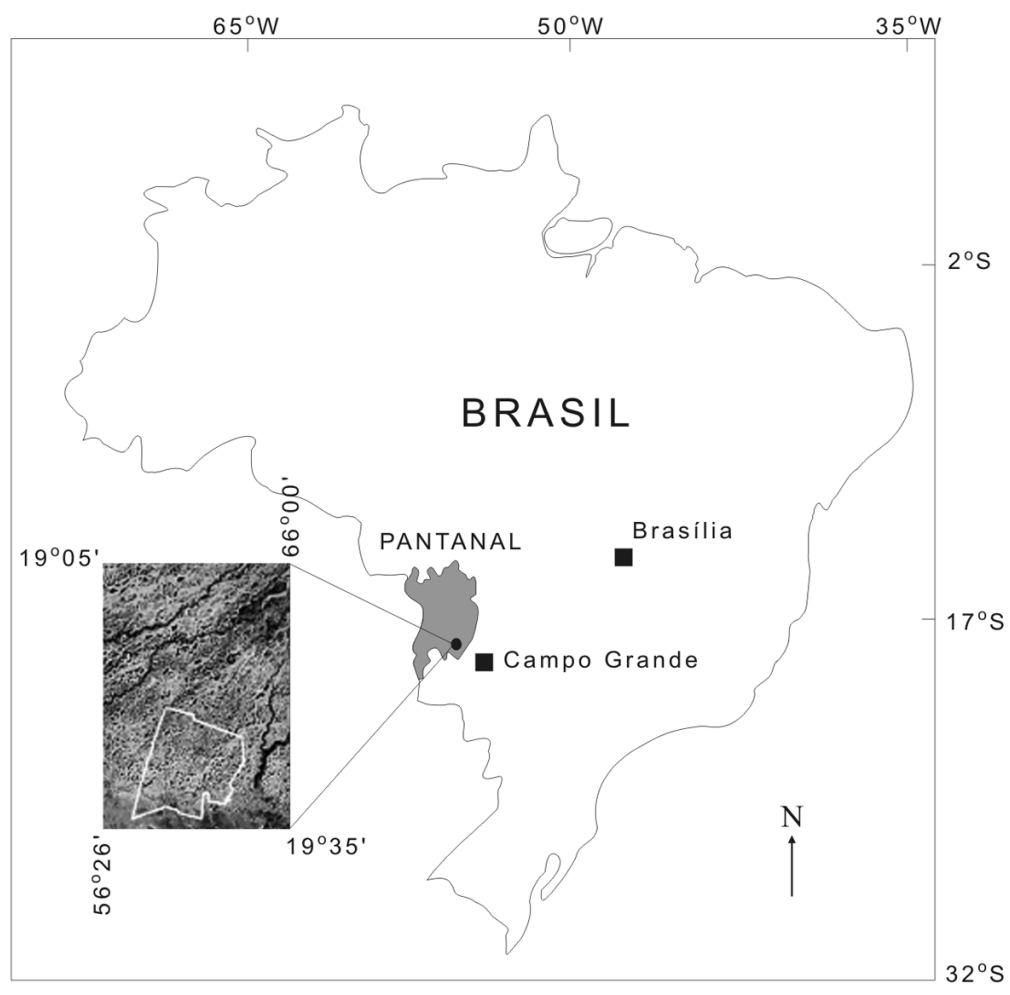

Fig. 1 - Localisation of Pantanal and the studied area (modified from Galvão et al. 2003).

$1100 \mathrm{~mm}$, lower than the annual evapo-transpiration rate of $1400 \mathrm{~mm}$ (Por 1995). Lower Nhecolândia, which is the study area, corresponds to the oldest depositional lobe of the Taquari alluvial fan (Assine 2004). It is distinguished from other sub-areas of the Pantanal by its uncommon physiography. This is characterised by the presence of seasonally flooded savannas limited by forest fragments growing over elevations 1-3 $\mathrm{m}$ in height (known locally as cordilheiras) and thousands of lakes with high spatial, physical, chemical and biological variability. These lakes are shallow, and are usually classified according to their $\mathrm{pH}$ and electric conductivity (EC; Almeida et al. 2003), $\mathrm{pH}$ and salinity (Costa and Telmer 2007), size, degree of roundedness and orientation (E. Fernandes, unpublished data).

The saline lakes, locally named salinas, have brackish-to-saline waters and basic $\mathrm{pH}$ (often above 10), are rarely deeper than $1 \mathrm{~m}$, with an average depth of approximately $50 \mathrm{~cm}$ in the rainy season (Galvão et al. 2003), and rarely become dry. They are distinguished by beaches devoid of vegetation ringed by a fringe of carandas palm trees (Copernicia alba Mo- rang) and Gramineae, which in turn is surrounded by carandas and Bromeliaceae popularly known as "caraguatá" (Aechmea spp.) and finally by the forest that covers the cordilheiras. These elevations completely surrounding the salinas protect them from the inflow of water during the floods.

The hyposaline lakes, locally named baias, are always devoid of beaches, have variable $\mathrm{pH}$ and low to-very-low salinity and can surpass $2 \mathrm{~m}$ in depth (Furquim et al. 2010), although most lakes are around $1 \mathrm{~m}$ in depth (Galvão et al. 2003). Aquatic vegetation is common. While surrounded by cordilheiras, the protection of the inflow of waters can be only partial. Carandas are absent from these cordilheiras, which have another species of palm tree of equal importance, popularly known as bocaiúva (Acrocomia aculeata Lodd), which are absent from the cordilheiras that surround the salinas (Almeida et al. 2003). Also notable are the relative altitudes of the saline and hyposaline lakes: Almeida et al. (2009), using precision equipment, measured the altitude of the 55 lakes studied, finding lower altitudes for the saline ones, and interpreted this as an 
evidence of geochemical erosion of sediments through quartz dissolution and reprecipitation of $\mathrm{SiO}_{2}$ as amorphous silica in the inter-granular spaces. This process occurs only in saline lakes, resulting in their location consistently below their hyposaline neighbours. The depth of the baias increases from the margins to the centre, unlike the salinas, which have flat sub-horizontal bottoms. This was interpreted by Almeida et al. (2009) as related to the interaction between the alkaline, silicarich solutions and the weakly acidic water table.

The $\mathrm{pH}$ variation is very important, ranging from slightly acid to very basic (Almeida et al. 2003, Costa and Telmer 2007). The salinity also varies strongly, with values of up to 286 times in lakes in relatively restricted geographical areas, according to Costa and Telmer (2007). Considering the sodium content as an indicator of salinity, the maximum difference was 27,145-fold (Barbiero et al. 2008). Such differences are essentially due to the greater isolation of the salinas from phreatic recharge by continuous horizons of greenish and grizzly soil of low porosity (Barbiero et al. 2008). Despite these different salinities, Barbiero et al. (2002) and Furquim et al. (2010) concluded that the salinas and baías waters belong to the same chemical family, excluding the possibility that the salinity is a legacy of past climatic periods. The isolation of the saline lakes is associated with high alkalinity, which helps to attack the quartzose sand and silt, supplying silica (in solution probably as $\mathrm{H}_{3} \mathrm{SiO}_{4}^{-}$or $\mathrm{H}_{2} \mathrm{SiO}_{4}^{2-}$ ) to precipitate $\mathrm{Mg}$ silicates (saponite and stevensite), illite and the amorphous silica cementing the grains of quartzose sand. This has been well described by Barbiero et al. (2008) and Furquim et al. (2008).

The lakes of Nhecolândia have some similarity to the soda lakes of the East African Rift Valley, considering the descriptions of Melack and Kilham (1974), Duckworth et al. (1996) and Jones et al. (1998). Like the Rift Valley lakes, the lakes of Nhecolândia have a water deficit (Por 1995, Barbiero et al. 2008). The waters are poor in $\mathrm{Ca}^{2+}$ and $\mathrm{Mg}^{2+}$ (Barbiero et al. 2002, Furquim et al. 2010), and there are frequent cyanobacteria blooms and an increase in salinity during the dry season (De-Lamonica-Freire and Heckman, 1996, Oliveira and Calheiros, 2000, Medina-Júnior and Rietzeler 2005). It is important to note that the hypothesis that alkalinisation in the lakes of Nhecolândia originates from carbonate massifs has been completely discarded. A biogeochemical origin, as in the Rift Valley lakes, is the only remaining possible explanation.

De-Lamonica-Freire and Heckman (1996) described 337 planktonic species in the northern part of the Pantanal, verifying a dominance of cyanobacterial species in the dry season and their absence during floods. Because the region is subjected to an intensely dry period between May and October, these authors suggested that the high proliferation of cyanobacteria is associated with increases in salinity, but did not show a relation between the bloom of these organisms and $\mathrm{pH}$, although there was a positive correlation with salinity, as is normal in alkaline lakes. In their quantitative study of the plankton species of the Paraguay River and its flood plains, Oliveira and Calheiros (2000) identified 82 species. Similar to De-Lamonica-Freire and Heckman (1996), these authors found that Chlorophyceae were prevalent and Cyanobacteriae were present only in the dry season. These studies confirm the general rule of nature, that the more severe the environmental conditions, the lower the biodiversity and the denser the population of surviving organisms (Sergeev et al. 2002) This explains the prevalence of cyanobacterial extremophiles in the saline waters of Nhecolândia, as observed in all prior studies (Oliveira and Calheiros 2000, Santos et al. 2004, Medina-Júnior and Rietzeler 2005, G. Mourão, unpublished data). The high evaporation rate during the dry season and the simultaneous biochemical processes (mainly the absorption of $\mathrm{CO}_{2}$ by phytoplanktonic productivity) increase the salinity and alkalinity to adverse levels for most phytoplanktonic species. Since the prevalence of any species in an environment depends on its superior survival ability (Tilman 1977), only the more resistant species will survive in high salinities and pHs. Cyanobacteria tend to occupy more ecologically adverse niches (Esteves 1998), and thereby have a higher survival ability. This explains why they were probably the first organisms to appear on Earth, as evidenced by fossils in rocks of 3.5 to $3.8 \mathrm{Ga}$ (Westall 2005). The high proliferation level of cyanobacteria is explained by the absence of competitors; their resistance to high salinity, high temperatures and low oxygen levels (Silva et al. 2008); their freedom 
from zooplankton predation; their accessory pigments such as phycobilins, which increase their capacity to absorb solar electromagnetic radiation in the green wavelength; and their ability to control their buoyancy and thereby migrate through the water column to enhance their photosynthetic activity (Shapiro 1990). It has been observed that shallow lakes favour the development of dense phytoplanktonic populations and that the salinas are shallower than the baías (Galvão et al. 2003). It is evident that in Nhecolândia there is a correlation between pH and salinity (Almeida et al. 2003, Galvão et al. 2003, Costa and Telmer 2007). This indicates that the alkalinisation and salinisation processes are interdependent. A correlation between salinity and phytoplanktonic activity has been described, but the possibility of cause and effect relationships among the alkalinity, salinity and phytoplanktonic activities has not been discussed in the literature.

The available data indicate that the Nhecolândia physiography arises from the complex and only partially understood combination of biological, hydrological, climatic, sedimentary, geochemical and neotectonic processes. To explain the diversity of lakes, however, we propose a hybrid process based on the phytoplankton activity and hydrogeochemistry of the saline and hyposaline lakes.

\section{ALKALINE LAKES AND THE BIOGEOCHEMICAL PROCESSES INVOLVED}

The geochemistry of calcium and its carbonates has a fundamental role in the preservation of the $\mathrm{pH}$ balance in waters: $\mathrm{pH}$ is increased through the dissolution of carbonates (releasing $\mathrm{HCO}_{3}^{2-}$ and $\mathrm{CO}_{3}^{2-}$ species into the water) and reduced through the precipitation of $\mathrm{CaCO}_{3}$ (removing $\mathrm{CO}_{3}^{2-}$ from water). Hence, the condition of neutral $\mathrm{pH}$, that is conducive for most terrestrial organisms, is attained in the presence of calcium, which stabilises the pH between 5.5 and 8.5 (Zavarzin 2002). According to this author, three routes of calcium capture can be considered: (1) abiotic chemical precipitation of carbonates of calcium, caused by physical and chemical imbalance in the water, such as the saturation of the solution because of evaporation; (2) a biological route where the carbonate precipitation is caused by the alkaline barrier created by the activity of microor- ganisms; and (3) direct precipitation in the construction of skeletons by intracellular mineralisation. The dissolution of the carbonates is caused by reverse processes: an increase in $\mathrm{CO}_{2}$ concentration by respiration in the oxygenated zone, or by the anaerobic generation of organic acids.

Soda lakes constitute the most natural alkaline environment on the planet, with $\mathrm{pHs}$ as high as 12 . The formation of such lakes requires low $\mathrm{Ca}^{2+}$ and high $\mathrm{Na}^{2+}$ contents, tropical arid or semi-arid zones with a water deficit, and salinisation through evaporation. The increase in the alkalinity is due to the disequilibrium in the $\mathrm{CO}_{2} / \mathrm{HCO}_{3}^{-} / \mathrm{CO}_{3}^{2-}$ system to $\mathrm{CO}_{3}^{2-}$ arising from the impossibility of precipitating $\mathrm{CaCO}_{3}$ (Duckworth et al. 1996). The persistence of alkaline lakes, however, requires a continuous process of alkalinisation to annul the buffering effect of $\mathrm{CO}_{2}$ (Jones et al. 1998). In agreement with McConnaughey and Whelan (1997), the most elementary mechanism of photosynthetic alkalinisation of water results from the liquid capture of $\mathrm{CO}_{2}$, leading to the concentration of $\mathrm{CO}_{3}^{2-}$ and $\mathrm{OH}^{-}$. If the water is oversaturated with $\mathrm{CaCO}_{3}$, precipitation is induced biogeochemically, with a resulting drop in $\mathrm{pH}$ to near neutrality and an enrichment of $\mathrm{Na}^{+}$and $\mathrm{Cl}^{-}$in the solution. By contrast, high primary photosynthetic productivity, mainly due to a dense cyanobacterial population during blooms, will bring a decrease in the dissolved $\mathrm{HCO}_{3}^{-}$and thereby a biogenic enrichment in $\mathrm{CO}_{3}^{2-}$. With a deficiency in $\mathrm{Ca}^{2+}$ to precipitate $\mathrm{CaCO}_{3}$, the $\mathrm{pH}$ necessarily rises (Visscher et al. 1998). Thompson and Ferris (1990), using cultures of Synechococcus, a cyanobacterium, demonstrated the pericellular precipitation of gypsum, calcite and magnesite parallel to an increase of the $\mathrm{pH}$ from 7.97 to 8.57 in 72 hours. This is a fast rate of alkalinisation, although in the experiment there were $\mathrm{Ca}^{2+}$ and $\mathrm{Mg}^{2+}$ present to minimise the $\mathrm{pH}$ increase.

Until recently, the enzyme carbonic anhydrase (CA) was known as an enzyme that catalyses the reversible hydration of $\mathrm{CO}_{2}\left(\mathrm{CO}_{2}+\mathrm{H}_{2} \mathrm{O} \leftrightarrows \mathrm{HCO}_{3}^{-}+\mathrm{H}^{+}\right)$in many eukaryotes. Close to the end of the 1990s it was discovered to be much more common and omnipresent in the domains of Archaea and Bacteria (Smith et al. 1999). Some eukaryotic algae can precipitate intracellular $\mathrm{CaCO}_{3}$ through the activity of CA. However, the 
cyanobacteria promote this activity only pericellularly. The internal $\mathrm{pH}$ of these organisms is neutral - their $\mathrm{CA}$ promotes external alkalinisation by $\mathrm{OH}^{-}$excretion, whereas fixing $\mathrm{CO}_{2}$ from $\mathrm{HCO}_{3}^{-}$generates pericellular $\mathrm{CaCO}_{3}$ precipitation (Kupriyanova et al. 2007). In other words, cyanobacteria promote the intense capture of inorganic carbon in the form of $\mathrm{CO}_{2}$ or $\mathrm{HCO}_{3}^{-}$not only by photosynthetic activity during blooms (similar to other microorganisms), but also by the extra cellular activity of $\mathrm{CA}$, which alkalinises their environment. For this reason, these organisms are particularly efficient in raising the $\mathrm{pH}$ of the water. According to Kupriyanova et al. (2007), the intensity of cyanobacterial CA activity is strictly controlled by $\mathrm{pH}$, with a maximum at $\mathrm{pH}$ 9.8, which is the ideal $\mathrm{pH}$ for these organisms. Thus, at $\mathrm{pH}>9.8$ the CA probably becomes increasingly less effective at raising alkalinity.

\section{MATERIALS AND METHODS}

Lakes were chosen for sampling using remote sensing images whose spectra were influenced by the phytoplankton content (Galvão et al. 2003). Real-colour TMLandsat 5 and AVNIR2-ALOS images were employed.

Three field campaigns were conducted to collect water samples in different seasons. Initially, these studies were planned for the same group of lakes at the Rio Negro farm, but only one set of water samples could be collected there, so the other two sets were acquired from the neighbouring Barranco Alto farm. The first set of samples was collected from 18 to 25 August 2007, in the middle of a rigorous drought. The second collection period was from 10 to 19 July 2008, at the beginning of drought, as the rainy season had extended into June. The third was from 6 to 10 October 2008, at the end of the normal dry season, but in a less intense drought than that of August 2007.

The three different groups of data are independent, considering the dynamics of the environment. At the same time, it was possible to compare a sub-set of samples, collected at two different climatic situations, from the same group of lakes. Finally, although the ensemble had problems (being sampled over two years), it is possible to consider three sets of samples: those taken at the beginning (July 2008), the middle (October 2008) and the end of the dry season (August 2007).
The temperature of the water $\left({ }^{\circ} \mathrm{C}\right)$, the $\mathrm{EC}$ $\left(\mu \mathrm{S} . \mathrm{cm}^{-1}\right)$, the dissolved oxygen $\left(\%\right.$ and $\left.\mathrm{mg} . \mathrm{L}^{-1}\right)$ and the $\mathrm{pH}$ were measured in situ with a multi-probe instrument (Yellow Springer, 556 MPS). Samples of water were collected close to the centre of the lakes in polyethylene flasks, filtered with Millex filters with a 0.45 membrane and then frozen. The samples of the first campaign were taken to the Laboratory of Groundwater Research Centre at the Institute of Geosciences of São Paulo University (USP) for cations analysis. $\mathrm{Na}^{+}$ and $\mathrm{K}^{+}$were analysed by flame photometry, and the other cations by atomic absorption spectrophotometry. The samples from the two other collection sets were sent to Activation Laboratories (Toronto, Canada) for similar cation analysis by ICP-OES or ICP-MS, according to the salinity identified in the field by EC. The anions were analysed by ion chromatography in the laboratories of the Engineering School of São Carlos (USP).

For the determination of phytoplankton, the water samples were collected and fixed with an acetic Lugol solution. The phytoplankton was counted using the sedimentation method (Uthermohl 1958). From the quantitative analysis, the total density (organisms. $\mathrm{mL}^{-1}$ ) was calculated according to the equation below (APHA 1995):

$$
D_{(\mathrm{org} / \mathrm{mL})}=\frac{C \times A t}{A f \times F \times V}
$$

where

$D=$ total density (organisms. $\mathrm{mL}^{-1}$ );

$C=$ number of organisms counted;

$A t=$ total surface area of the sedimentary bed $\left(\mathrm{mm}^{2}\right)$;

$A f=$ surface area of the field of counting $\left(\mathrm{mm}^{2}\right)$;

$F=$ number of counted fields;

$V=$ volume of the sediment $(\mathrm{mL})$.

The relative abundance was estimated considering the number of individuals of each species and the total number of individuals, according to the classification of McCullough and Jackson (1985): 50 to $100 \%$, dominant organisms; 30 to $49 \%$, abundant organisms; 10 to $29 \%$, common organisms; 1 to $9 \%$, occasional organisms; $<1 \%$, rare organisms.

To determine the concentrations of chlorophyll $a$ and pheophytin, the samples were filtered through glass microfibre membranes (Millipore AP 20; $47 \mathrm{~mm}$ diameter and $8.0 \mu \mathrm{m}$ porosity), and stored frozen until the 
TABLE I

Classification by EC ( $\left.\mu \mathrm{S} . \mathrm{cm}^{-1}\right)$ adopted for the lake waters studied and the approximate content of total dissolved solids (TDS) calculated by the mean value reported in APHA (1995).

\begin{tabular}{l|c|c}
\hline Classes of waters & $\begin{array}{c}\text { EC } \\
\left(\mu \mathrm{S} . \mathrm{cm}^{-1}\right)\end{array}$ & $\begin{array}{c}\text { Approximated } \\
\text { TDS }\left(\mathrm{g} . \mathrm{L}^{-1}\right)\end{array}$ \\
\hline Freshwater & $<100$ & $<0.06$ \\
\hline Water with low or average salinity & 100 to 750 & 0.06 to 0.5 \\
\hline Water with high salinity & 750 to 2250 & 0.5 to 1.4 \\
\hline Water with very high salinity & 2250 to 5000 & 1.4 to 3.1 \\
\hline Hypersaline water & $>5000$ & $>3.1$ \\
\hline
\end{tabular}

moment of extraction. Ethanol at $80 \%$ was used for the extraction. The spectrophotometric analysis of the extracts was performed according to APHA (1995), and the reading was done between wavelengths of 665 and $750 \mathrm{~nm}$. For the determination of chlorophyll $a\left(\mu \mathrm{gL}^{-1}\right)$ and pheophytin $\left(\mu \mathrm{g} . \mathrm{L}^{-1}\right)$, the following formulas were used as in Nush (1980):

$$
\begin{gathered}
\text { Chlorophyll } a=29.6 \\
\times\left\{\left(E u_{665}-E u_{750}\right)-\left(E a_{665}-E a_{750}\right)\right\} \\
\times v / V \times s \\
\text { Pheophytin }=29.6 \\
\times\left\{\left[1.7 \times\left(E a_{665}-E a_{750}\right)\right]-\left(E u_{665}-E u_{750}\right)\right\} \\
\times v / V \times s
\end{gathered}
$$

where:

$E u=$ absorbance of the unacidified sample;

$E a=$ absorbance of the acidified sample;

$v=$ volume of the bed (mL);

$V=$ volume of the filtered sample (L);

$s=$ thickness of the cuvette $(\mathrm{cm})$;

$29.6=$ specific absorption coefficient of chlorophyll $a$;

$1.7=$ ratio of the yield of unacidified to acidified chlorophyll $a$.

The quantitative and qualitative analyses of the phytoplankton and chlorophyll concentrations were done in the Laboratory of Biotoxicology of Continental Waters, of the USP School of Engineering, São Carlos campus.

The Rio Negro farm samples were given the general acronym $\mathrm{RN}$, added to the lake code according to the sampling order, and the letter " $\mathrm{s}$ " for salinas or " $\mathrm{b}$ " for baias. Samples from the Barranco Alto farm have only the BA acronym followed by the lake number. All water samples were classified by their EC proportional to the salinity according to Table I, modified from the classification by USSL (1954).

\section{RESULTS AND DISCUSSION}

In August 2007 at the Rio Negro farm, water from 15 lakes was sampled for limnological and hydrogeochemical analyses. Eight of these lakes were salinas $(\mathrm{EC}>$ $750 \mu \mathrm{S} . \mathrm{cm}^{-1}$ ). In July 2008, 28 lakes were sampled, of which 14 were salinas. In October 2008, 19 lakes were sampled for hydrogeochemistry and 14 for limnological analyses, of which seven were EC $<750 \mu{\mathrm{S} . \mathrm{cm}^{-1}}^{-1}$ and $12 \mathrm{EC}>2,000 \mu \mathrm{S} . \mathrm{cm}^{-1}$. The results of the chemical analyses showed that all the waters were extremely poor in $\mathrm{Ca}^{2+}$ and $\mathrm{Mg}^{2+}$ but, in the salinas, rich in $\mathrm{Na}^{+}$ and $\mathrm{K}^{+}$, as stated in the general literature (Zavarzin 2002) and that on Nhecolândia (Barbiero et al. 2002, Furquim et al. 2008). Table II presents the results of the August 2007 sampling, where the poverty in $\mathrm{Ca}^{2+}$ and $\mathrm{Mg}^{2+}$ ions is clear. The independence of these cations with regard to $\mathrm{EC}$ and $\mathrm{pH}$ is evident. The $\mathrm{Na}$ and $\mathrm{K}$ cations have a high correlation with $\mathrm{EC}$, as expected, it being almost perfect in the case of $\mathrm{Na}^{+}$if we ignore sample RN7S $\left(\mathrm{R}^{2}=0.9997\right)$.

The fieldwork at the Barranco Alto estate, in July and October 2008 yielded similar results (Table III). For most of the water samples with a high $\mathrm{pH}$, the content of dissolved calcium was below the detection limit, as expected, because, in these conditions, $\mathrm{Ca}^{2+}$ precipitates as $\mathrm{CaCO}_{3}$. It is important to observe that the high $\mathrm{Na}^{+}$and $\mathrm{K}^{+}$content occurred only in the saline lakes because of evaporation from the lakes, which are isolated from phreatic recharge. As regards the phytoplanktonic 
TABLE II

EC, $\mathbf{p H}$ and content in mg. $\mathrm{L}^{-1}$ of $\mathrm{Ca}^{2+}, \mathrm{Mg}^{2+}, \mathrm{Na}^{+}$and $\mathrm{K}^{+}$ of samples from the Rio Negro farm lakes (August 2007).

\begin{tabular}{c|c|c|c|c|c|c}
\hline \multirow{2}{*}{ Lake } & \multirow{2}{*}{$\begin{array}{c}\mathrm{EC} \\
\mathrm{S} . \mathrm{cm}^{-1}\end{array}$} & $\mathrm{pH}$ & $\mathrm{Ca}$ & $\mathrm{Mg}$ & $\mathrm{Na}$ & $\mathrm{K}$ \\
\cline { 3 - 7 } & 30 & 8.11 & 2.8 & 2.0 & 8.3 & 6.7 \\
\hline RN1B & 2858 & 9.41 & 3.7 & 0.14 & 906 & 340 \\
\hline RN1S & 74 & 8.52 & 5.1 & 4.5 & 12.3 & 9.5 \\
\hline RN2B & 9.06 & 6.6 & 4.1 & 1060 & 245 \\
\hline RN2S & 3467 & 9.1 & \multicolumn{5}{|c}{$\mathrm{mg}^{-1}$} \\
\hline RN3B & 110 & 7.13 & 4.6 & 4.8 & 23.1 & 17.2 \\
\hline RN3S & 2429 & 9.7 & 4.7 & 0.15 & 762 & 293 \\
\hline RN4S & 2798 & 9.37 & 4.1 & 3.1 & 813 & 155 \\
\hline RN5B & 591 & 7.32 & 4.2 & 8.1 & 152 & 36.1 \\
\hline RN5S & 7156 & 9.4 & 2.9 & 0.26 & 2222 & 478 \\
\hline RN6B & 42 & 8.28 & 1.8 & 2.0 & 4.7 & 9.4 \\
\hline RN6S & 11500 & 9.41 & 11.0 & 0.91 & 3600 & 805 \\
\hline RN7B & 27 & 7.33 & 0.98 & 1.1 & 7.5 & 4.9 \\
\hline RN7S & 8572 & 9.51 & 4.5 & 1.0 & 1353 & 280 \\
\hline
\end{tabular}

material, 28 lakes (salinas and baias) were sampled in the first round and 19 in the second.

Table IV shows the percentages of lakes in relation to the classes of the prevalent phytoplanktonic organisms in each of the five classes of water as described in Table I. The 61 samples, as well as each contemporaneous set, confirm the conclusion of Oliveira and Calheiros (2000), Santos et al. (2004), Oduor and Schagerl (2007) and Santos and Sant'Anna (2010) that cyanobacteria are more prevalent in more saline waters. When the results from the same groups of lakes sampled in July and October 2008 are compared, the seasonal variations replicate the findings of other authors. The sampling of August 2007 does not represent a climatically intermediate situation, as indicated by the salinity and stable isotope data, possibly reflecting climatic differences between 2007 and 2008. Two readings could be made from Table IV: the seasonal evolution and, for each sample collection, the distribution of classes of organisms as a function of salinity. For the July 2008 collection, a continuous increase in the proportion of cyanobacteria was observed in relation to the salinity. For the August 2007 sample collection, the distribution was irregular, though with a clear tendency towards the growing dominance of cyanobacteria in the high-salinity lakes. However, this does not give an intermediary view between the sample collections of July and October 2008. These data show the difficulty in comparing, for detailed observations, different lakes and sample collections from different years. We were surprised to find, among the high salinity lakes, with $\mathrm{EC}>5000 \mu \mathrm{S} . \mathrm{cm}^{-1}$, a lake with a predominance of Bacillariophyceae rather than Cyanobacteriae. Finally, for the October 2008 collection, normally the most adverse situation because it would be at the end of the dry season, cyanobacteria were prevalent even in lakes with low-to-medium salinity. However, Chlorophyceae were dominant in a lake of high salinity. The seasonal tendency is clear for the sample collections taken from the same lakes; namely, there is an increase of cyanobacterial dominance during the dry season. In relation to the salinity, the water classes have the same tendency, with the prevalence of cyanobacteria in the most saline waters. Considering the number of genera and species (Table V), the tendency for the increase of cyanobacteria is continuous from the freshwater to very saline waters. However, there is an unexpectedly reduced presence of cyanobacteria in the hypersaline water class.

The diversity of phytoplankton and the proportion of cyanobacteria in relation to all phytoplankton organisms are, in general, highly correlated to water classes from Table I (Tables VI and VII). The low number of 
TABLE III

EC, $\mathrm{pH}$ and content in $\mathrm{mg} / \mathrm{L}$ of $\mathrm{Ca}^{2+}, \mathrm{Mg}^{2+}, \mathrm{Na}^{+}$and $\mathrm{K}^{+}$of samples from the Barranco Alto farm lakes in July and October 2008.

\begin{tabular}{|c|c|c|c|c|c|c|c|c|c|c|c|c|}
\hline \multirow[b]{2}{*}{ Lake } & \multicolumn{6}{|c|}{ First sampling (July 2008) } & \multicolumn{6}{|c|}{ Second sampling (October 2008) } \\
\hline & $\begin{array}{c}\mathrm{EC} \\
\mathrm{uS} / \mathrm{cm}\end{array}$ & $\mathrm{pH}$ & $\begin{array}{c}\mathrm{Ca} \\
\mathrm{mg} / \mathrm{L}\end{array}$ & $\begin{array}{c}\mathrm{Mg} \\
\mathrm{mg} / \mathrm{L}\end{array}$ & $\begin{array}{c}\mathrm{Na} \\
\mathrm{mg} / \mathrm{L}\end{array}$ & $\begin{array}{c}\mathrm{K} \\
\mathrm{mg} / \mathrm{L}\end{array}$ & $\begin{array}{c}\mathrm{EC} \\
\mathrm{uS} / \mathrm{cm}\end{array}$ & $\mathrm{pH}$ & $\begin{array}{c}\mathrm{Ca} \\
\mathrm{mg} / \mathrm{L}\end{array}$ & $\begin{array}{c}\mathrm{Mg} \\
\mathrm{mg} / \mathrm{L}\end{array}$ & $\begin{array}{c}\mathrm{Na} \\
\mathrm{mg} / \mathrm{L}\end{array}$ & $\begin{array}{c}\mathrm{K} \\
\mathrm{mg} / \mathrm{L} \\
\end{array}$ \\
\hline BA01 & 25 & 6.02 & 1.4 & 0.8 & 2.1 & 3.6 & 36 & 7.89 & 1.7 & 0.848 & 1.53 & 4.27 \\
\hline BA02 & 113 & 7.09 & 4.3 & 2.3 & 12.4 & 13.6 & 161 & 8.35 & 4.6 & 1.62 & 22 & 17.5 \\
\hline BA03 & 172 & 7.77 & 4.6 & 2.6 & 22.3 & 17.9 & 229 & 8.77 & 6.3 & 1.95 & 40.1 & 19.8 \\
\hline BA04 & 77 & 4.88 & 2.5 & 0.6 & 22.8 & 5.4 & - & - & - & - & - & - \\
\hline BA05 & 3185 & 9.3 & $<0.6$ & 0.29 & 744 & 128 & 4567 & 9.21 & $<0.6$ & 0.57 & 871 & 148 \\
\hline BA07 & 2932 & 9.31 & $<0.6$ & 0.99 & 803 & 178 & 5641 & 9.6 & $<0.6$ & 1.21 & 1130 & 250 \\
\hline BA08 & 27 & 5.89 & 0.7 & 0.4 & 5.2 & 3 & - & - & - & - & - & - \\
\hline BA09 & 4140 & 9.44 & $<0.6$ & 5.56 & 837 & 148 & 6607 & 9.67 & $<0.6$ & 3.19 & 1330 & 198 \\
\hline BA12A & 1045 & 8.71 & $<0.6$ & 0.74 & 14.6 & 3.9 & - & - & - & - & - & - \\
\hline BA12B & 1160 & 8.98 & 7.4 & 2.15 & 0.448 & 98.2 & - & - & - & - & - & - \\
\hline BA14 & 2517 & 9.49 & $<0.6$ & 0.45 & 542 & 166 & - & - & - & - & - & - \\
\hline BA16 & 3618 & 9.46 & 12 & 1.16 & 1320 & 359 & 8410 & 9.77 & 13 & 2.87 & 1680 & 430 \\
\hline BA21 & 7188 & 9.33 & 15 & 1.97 & 2730 & 324 & 16360 & 9.78 & 22 & 4.05 & 3340 & 799 \\
\hline BA22 & 5357 & 9.25 & $<0.6$ & 1.69 & 1770 & 207 & 12870 & 9.67 & $<0.6$ & 1.57 & 2410 & 597 \\
\hline BA23 & 40 & 6.74 & 2.8 & 0.8 & 9.6 & 5 & 79 & 5.69 & 3.4 & 0.956 & 13.7 & 6.63 \\
\hline BA24 & 1590.5 & 9.38 & 13 & 1.75 & 527 & 139 & 3976 & 10.06 & 11 & 2.8 & 843 & 159 \\
\hline BA25 & 710 & 9.28 & $<0.6$ & 0.41 & 260 & 103 & 2317 & 9.68 & $<0.6$ & 0.71 & 332 & 141 \\
\hline BA26 & 2671 & 9.5 & 12 & 1.41 & 980 & 227 & 6857 & 9.85 & 25 & 3.85 & 1540 & 342 \\
\hline BA27 & 10 & 6.5 & 0.6 & 0.4 & 2.8 & 2.8 & 67 & 6.9 & 2.5 & 0.98 & 5.72 & 5.37 \\
\hline BA30 & 81 & 7.69 & 5.9 & 2.3 & 16.2 & 19 & 225 & 6.35 & 2.2 & 0.867 & 15.8 & 37.7 \\
\hline BA31 & 95 & 6.5 & 2.1 & 1.08 & 18.2 & 34 & 170 & 8.69 & 6.8 & 2.73 & 14.5 & 20.2 \\
\hline BA32 & 154 & 7.74 & 5.5 & 3.2 & 35.9 & 29.5 & - & - & - & - & - & - \\
\hline BA33 & 438 & 9.52 & 1.9 & 0.2 & 356 & 110 & - & - & - & - & - & - \\
\hline BA34 & 1001 & 9 & 2.9 & 0.26 & 0.321 & 158 & - & - & - & - & - & - \\
\hline BA35 & 780 & 9.09 & $<0.6$ & 1.23 & 229 & 196 & 2032 & 9.45 & $<0.6$ & 1 & 199 & 191 \\
\hline BA36 & 940 & 8.89 & 3.7 & 1.42 & 0.316 & 111 & 2116 & 9.19 & $<0.6$ & 0.84 & 320 & 128 \\
\hline BA37 & 1750 & 9.28 & $<0.6$ & 0.28 & 600 & 127 & 3940 & 7.98 & $<0.6$ & 0.47 & 791 & 173 \\
\hline BA40 & 36 & 7.89 & 1.8 & 0.911 & 2.5 & 6.26 & - & - & - & - & - & - \\
\hline
\end{tabular}

genera and species in the freshwater lakes could be because more complete limnological data were taken from only one freshwater lake, thereby artificially reducing the diversity. For the other classes, the pattern of diversity reduction with salinity increase is clear, above all when all data are considered. It is clear that this cyanobacteria association is more prevalent in more saline waters, except for the hypersaline class (Table VI and VII). In the latter, only cyanobacteria were expected, because they are extremophiles organisms, thus more adaptable at a hypersaline environ- ment. However, they have a lesser presence than in the highly saline class lakes, yielding more space for Chlorophyceae and Cryptophyceae (Table V). If this situation was observed in only one field campaign, it might be considered an exception. Because it was seen in all three field campaigns, it suggests an unexpected and unexplained trend. Table VII shows that, for the other salinity groups, there is a distinct increase in cyanobacterial dominance from the beginning to the end of the dry season except in the hypersaline waters, where their dominance remained the same. 
TABLE IV

Distribution of the percentage of classes of prevalent phytoplankton organisms in relation to the total number of phytoplanktonic classes described for the groups of lakes classified according to Table I. Cyanobacteria $=$ Cyano; Chlorophyceae $=$ Chloro; Bacillariophyceae $=$ Bacill; Cryptophyceae $=$ Crypto; Dinophyceae $=$ Dinophy .

\begin{tabular}{l|c|c|c|c|c}
\hline \multirow{2}{*}{ Class of water } & \multicolumn{4}{|c}{ Class of prevalent organisms (\% of lakes) } \\
\cline { 2 - 6 } & Cyano & Chloro & Bacill & Crypto & Dinophy \\
\hline Freshwater (July 2008) $\mathrm{n}=7$ & 25 & 25 & 0 & 50 & 0 \\
\hline Freshwater (August 2007) $\mathrm{n}=4$ & 50 & 25 & 0 & 0 & 25 \\
\hline Freshwater (October 2008) $\mathrm{n}=1$ & 25 & 75 & 0 & 0 & 0 \\
\hline Average for freshwater & $\mathbf{3 3 . 3}$ & $\mathbf{4 1 . 7}$ & $\mathbf{0 . 0}$ & $\mathbf{1 6 . 7}$ & $\mathbf{8 . 3}$ \\
\hline Low to average salinity (July 2008) $\mathrm{n}=5$ & 66 & 33 & 0 & 0 & 0 \\
\hline Low to average salinity (August 2007) $\mathrm{n}=3$ & 0 & 33 & 0 & 66 & 0 \\
\hline Low to average salinity (October 2008) $\mathrm{n}=4$ & 100 & 0 & 0 & 0 & 0 \\
\hline Average of low to average salinity & $\mathbf{5 5 . 3}$ & $\mathbf{2 2 . 0}$ & $\mathbf{0 . 0}$ & $\mathbf{2 2 . 0}$ & $\mathbf{0 . 0}$ \\
\hline High salinity (July 2008) $\mathrm{n}=8$ & 75 & 25 & 0 & 0 & 0 \\
\hline High salinity (August 2007) $\mathrm{n}=0$ & $*$ & $*$ & $*$ & $*$ & $*$ \\
\hline High salinity (October 2008) $\mathrm{n}=4$ & 87.5 & 12.5 & 0 & 0 & 0 \\
\hline Average of high salinity & $\mathbf{7 9 . 2}$ & $\mathbf{1 8 . 8}$ & $\mathbf{0 . 0}$ & $\mathbf{0 . 0}$ & $\mathbf{0 . 0}$ \\
\hline Very high salinity (July 2008) $\mathrm{n}=6$ & 80 & 20 & 0 & 0 & 0 \\
\hline Very high salinity (August 2007) $\mathrm{n}=4$ & 50 & 25 & 25 & & 0 \\
\hline Very high salinity (October 2008) $\mathrm{n}=4$ & 100 & 0 & 0 & 0 & 0 \\
\hline Average of very high salinity & $\mathbf{7 6 . 7}$ & $\mathbf{1 5 . 0}$ & $\mathbf{8 . 3}$ & $\mathbf{0 . 0}$ & $\mathbf{0 . 0}$ \\
\hline Hypersaline (July 2008) $\mathrm{n}=2$ & 100 & 0 & 0 & 0 & 0 \\
\hline Hypersaline (August 2007) $\mathrm{n}=4$ & 75 & 0 & 25 & 0 & 0 \\
\hline Hypersaline (October 2008) $\mathrm{n}=1$ & 100 & 0 & 0 & 0 & 0 \\
\hline Average of hypersaline & $\mathbf{9 1 . 7}$ & $\mathbf{0 . 0}$ & $\mathbf{8 . 3}$ & $\mathbf{0 . 0}$ & $\mathbf{0 . 0}$ \\
\hline
\end{tabular}

Analysis of the density of organisms in the two sample collections from the Barranco Alto farm with the $\mathrm{EC}$ and $\mathrm{pH}$ data (Table VIII) demonstrated two different behaviours. The freshwater lakes with the phreatic recharge had a small increase in salinity with increased $\mathrm{pH}$, essentially because of the activity of microorganisms. The lakes with saline water had a $\mathrm{pH}$ increase related to more intense activity of microorganisms, including blooms, but with a large increase in salinity because of evaporation. The greatest geochemical imbalance was caused by intense evaporation over lakes that are necessarily isolated from the water table. It was observed that:

(1) in the sample collections at the end of the dry season, three lakes showed cell densities $>10^{6}$;

(2) these lakes have higher $\mathrm{pHs;}$

(3) the lakes with higher EC had a low density of organisms at the beginning of the dry season and the greatest density at the end of dry season;
(4) the highest $\mathrm{pH}$ in the samples collected at the end of the dry season was related to an EC far lower than that of the lakes with $\mathrm{pH}>9$.

These data enable us to visualise the existence of two independent processes that increase the lakes' $\mathrm{pH}$, as proposed by Zavarzin (2002): (1) increasing salinity through evaporation (directly associated to the degree of isolation of the lake from the phreatic recharge); and (2) the increasing density of organisms (directly associated to the high proliferation rate of phytoplankton). The BA21 lake at the beginning of the dry season had a high $\mathrm{pH}$ and the highest EC of the sampled group. With the EC increasing towards the highest value found in all the campaigns (and therefore the highest salinity), the isolation of this lake and the favourable conditions for an intense phytoplankton bloom are clearly evident. This bloom was probably partly responsible for the increase in $\mathrm{pH}$, because the EC increased 2.3 fold (a sim- 
TABLE V

Number of genera and species described by salinity of water classes adopted $(G=G e n u s ; s p=$ species $)$.

\begin{tabular}{|c|c|c|c|c|c|c|}
\hline \multirow{2}{*}{\multicolumn{2}{|c|}{ Class of organisms }} & \multicolumn{5}{|c|}{ Class of water (all the lakes) } \\
\hline & & \multirow{2}{*}{$\begin{array}{c}\text { Freshwater } \\
8 \\
\end{array}$} & \multirow{2}{*}{$\begin{array}{c}\text { Low to average } \\
\text { salinity }\end{array}$} & \multirow{2}{*}{$\begin{array}{c}\begin{array}{c}\text { High } \\
\text { salinity }\end{array} \\
15\end{array}$} & \multirow{2}{*}{$\begin{array}{l}\begin{array}{c}\text { Very high } \\
\text { salinity }\end{array} \\
23\end{array}$} & \multirow{2}{*}{$\begin{array}{c}\text { Hypersaline } \\
6\end{array}$} \\
\hline Cyanohacteria & $\mathrm{G}$ & & & & & \\
\hline Cyantovacterid & $\mathrm{sp}$ & 8 & 13 & 20 & 27 & 7 \\
\hline \multirow{2}{*}{ Chlorophyceae } & G & 25 & 27 & 16 & 0 & 6 \\
\hline & $\mathrm{sp}$ & 33 & 44 & 17 & 0 & 6 \\
\hline \multirow{2}{*}{ Bacillariophyceae } & G & 5 & 4 & - & 6 & 0 \\
\hline & $\mathrm{sp}$ & 5 & 4 & 0 & 6 & 0 \\
\hline \multirow{2}{*}{ Cryptophyceae } & G & 2 & 3 & 9 & 0 & 3 \\
\hline & $\mathrm{sp}$ & 2 & 3 & 9 & 0 & 3 \\
\hline \multirow{2}{*}{ Dinophyceae } & G & 1 & 2 & 0 & 1 & 0 \\
\hline & $\mathrm{sp}$ & 1 & 2 & 0 & 1 & 0 \\
\hline \multirow{2}{*}{ Chrysophyceae } & $\mathrm{G}$ & 1 & 1 & 0 & 0 & 0 \\
\hline & $\mathrm{sp}$ & 1 & 1 & 0 & 0 & 0 \\
\hline \multirow{2}{*}{ Euglenophyceae } & G & 3 & 3 & 0 & 3 & 0 \\
\hline & $\mathrm{sp}$ & 3 & 3 & 0 & 3 & 0 \\
\hline \multirow{2}{*}{ All the organisms } & $G$ & 45 & 49 & 40 & 33 & 15 \\
\hline & $\mathrm{sp}$ & 53 & 70 & 46 & 37 & 16 \\
\hline
\end{tabular}

TABLE VI

Number of species of phytoplanktonic organisms observed in the lake samples from the Rio Negro farm and the relative percentage of cyanobacteria. Sampling was done in August 2007.

\begin{tabular}{l|c|c}
\hline Class of water & $\begin{array}{c}\text { All } \\
\text { species }\end{array}$ & $\begin{array}{c}\text { \% Species of } \\
\text { cyanobacteria }\end{array}$ \\
\hline Freshwater (four lakes) & 52 & 15 \\
\hline Low to average salinity (three lakes) & 69 & 19 \\
\hline High salinity (five lakes) & 46 & 43 \\
\hline Very high salinity (four lakes) & 37 & 73 \\
\hline Hypersaline (two lakes) & 16 & 44 \\
\hline
\end{tabular}

TABLE VII

Species of phytoplankton observed in the lake samples from the Barranco Alto farm and the relative percentage of cyanobacteria. The first sample collection was done in July 2008 and the second in October 2008.

\begin{tabular}{l|c|c|c|c}
\hline \multirow{2}{*}{ Class of water } & \multicolumn{2}{|c|}{ All species } & \multicolumn{2}{c}{ \% Species of cyanobacteria } \\
\cline { 2 - 5 } & 1st sampling & 2nd sampling & 1st sampling & 2nd sampling \\
\hline Freshwater & 11 & 9 & 9 & 44 \\
\hline Low to average salinity & 28 & 31 & 25 & 29 \\
\hline High salinity & 18 & 24 & 22 & 58 \\
\hline Very high salinity & 15 & 17 & 87 & 100 \\
\hline Hypersaline & 9 & 12 & 44 & 44 \\
\hline
\end{tabular}


TABLE VIII

Density of organisms, EC and pH of the samples of October 2008.

The highest pHs are related to the highest density of organisms in extreme dryness (bold characters and grey lines). Data ordered by $\mathrm{pH}$ of the second sampling.

\begin{tabular}{c|c|c|c|c|c|c}
\hline \multicolumn{3}{c}{$\begin{array}{c}\text { Density of organisms } \\
\text { (org.mL } \mathrm{mL}^{-1} \text { ) }\end{array}$} & \multicolumn{2}{c|}{ First sampling } & \multicolumn{2}{c}{ Second sampling } \\
\cline { 4 - 7 } & EC & $\mathrm{pH}$ & $\mathrm{EC}$ & $\mathrm{pH}$ \\
\hline Lakes & First sampling & Second sampling & $\mu{\mathrm{S} . \mathrm{cm}^{-1}}^{-1}$ & & $\mu{\mathrm{S} . \mathrm{cm}^{-1}}^{-}$ & \\
\hline BA37 & 61,726 & 119,019 & 1750 & 9.28 & 3940 & 7.98 \\
\hline BA2 & 23,493 & 13,727 & 113 & 7.09 & 161 & 8.35 \\
\hline BA31 & 630 & 35,141 & 95 & 6.5 & 170 & 8.69 \\
\hline BA3 & 27,178 & 144,697 & 172 & 7.77 & 229 & 8.77 \\
\hline BA36 & 148 & 284 & 940 & 8.89 & 2116 & 9.19 \\
\hline BA5 & 354,695 & 12,319 & 3185 & 9.3 & 4567 & 9.21 \\
\hline BA35 & 51,795 & 212,641 & 780 & 9.09 & 2032 & 9.45 \\
\hline BA7 & 204,986 & 257,568 & 2932 & 9.31 & 5641 & 9.6 \\
\hline BA9 & 23,402 & 95,077 & 4140 & 9.44 & 6607 & 9.67 \\
\hline BA25 & 18,759 & 6,909 & 710 & 9.28 & 2317 & 9.68 \\
\hline BA16 & $\mathbf{1 , 0 3 2 , 9 9 0}$ & $\mathbf{2 , 7 6 3 , 8 5 4}$ & $\mathbf{3 6 1 8}$ & $\mathbf{9 . 4 6}$ & $\mathbf{8 4 1 0}$ & $\mathbf{9 . 7 7}$ \\
\hline BA21 & $\mathbf{1 2 3 , 2 5 6}$ & $\mathbf{1 0 , 4 4 3 , 8 4 2}$ & $\mathbf{7 1 8 8}$ & $\mathbf{9 . 3 3}$ & $\mathbf{1 6 3 6 0}$ & $\mathbf{9 . 7 8}$ \\
\hline BA24 & $\mathbf{4 0 1 , 8 6 2}$ & $\mathbf{1 , 0 2 0 , 3 2 3}$ & $\mathbf{1 5 9 1}$ & $\mathbf{9 . 3 8}$ & $\mathbf{3 9 7 6}$ & $\mathbf{1 0 . 0 6}$ \\
\hline
\end{tabular}

ilar pattern to the average of all the lakes -2.1 times), whereas the density of organisms increased 85 fold. This suggests that two processes act to increase the $\mathrm{pH}$ and alkalinity: one geochemical and other biogenic. Analysis of the densities of organisms in lakes BA16, BA21 and BA24 show that the latter had the highest $\mathrm{pH}$ of the group and the lowest density of organisms. The data could indicate that, in this case, the alkalinisation was simply dominated by physicochemical processes, such as evidenced by the geochemical imbalance in evaporation. Another possibility is that when the $\mathrm{pH}$ attain the peak of 9.8, there are a fall in CA activity, reducing the productivity of these organisms. Both hypotheses could explain a small increase in the cyanobacterial population in the most alkaline lake, with a $\mathrm{pH}>10$, but the latter seems more convincing because the EC of lake BA24 was not particularly high.

Arranging the data according to the population density of the organisms, the six lakes with density $>150,000$ org. $\mathrm{mL}^{-1}$ coincided with the five lakes with the highest $\mathrm{pHs}$ and with five of the eight lakes with a $\mathrm{EC}>750 \mathrm{gS} . \mathrm{cm}^{-1}$, indicating a significant correlation (Table IX). By contrast, the lake with the highest EC had one of the lowest densities of organisms, and one of the lakes with the highest density of organisms had one of the lowest ECs, an evidence that phytoplankton blooms are not strictly dependent on EC (or salinity). However, ordering the data by $\mathrm{pH}$, the five highest $\mathrm{pHs}$ were associated with five of the six highest microorganism densities. Finally, in these two groups of independent data (the lakes from the Rio Negro and Barranco Alto farms), the highest densities were linked to the highest salinities, suggesting that the most intense blooms occur in those lake waters more isolated from the phreatic zone. The fact that all the studied lakes with $\mathrm{pH}>9.0$ in October had very high salinity or hypersalinity suggests a causal relationship between the processes of isolation and alkalinisation of these lakes.

In the August 2007 fieldwork data (Table X), there is an evident correlation between the chlorophyll and pheophytin pigments with $\mathrm{pH}$. Considering that only cyanobacteria have pheophytin and that organisms of other classes were described in all the classes of water, the sum of these two pigments was considered more representative of the biogenic contribution to increased $\mathrm{pH}$.

The data concerning pigments in the samples of the fieldworks of 2008 are clear (Table XI). In the two sample collections, there were two contrasting groups of samples: those with low pigment levels and those 
TABLE IX

Density of organisms, EC and pH of the August 2007 sampling. The data are ordered by $\mathrm{pH}$ on the left and by EC on the right. The highest pHs are related to the highest density of organisms, and there is a greater independence from EC.

The data showing the higher density of organisms, $\mathrm{pH}$ and EC are in bold characters.

\begin{tabular}{c|c|c|c||c|c|c|c}
\hline Lake & $\begin{array}{c}\text { Density of } \\
\text { organisms } \\
\text { org.mL }\end{array}$ & $\mathrm{pH}$ & $\begin{array}{c}\mathrm{EC} \\
\mu \mathrm{S}^{-1} \mathrm{~cm}^{-1}\end{array}$ & Lake & $\begin{array}{c}\text { Density of } \\
\text { organisms } \\
\text { org.mL }\end{array}$ & $\mathrm{pH}$ & $\begin{array}{c}\mathrm{EC} \\
\mu \mathrm{S}^{-1} \mathrm{~cm}^{-1}\end{array}$ \\
\hline RN 3b & 300 & 7.13 & 110 & RN 7b & 1100 & 7.33 & 27 \\
RN 4b & 900 & 7.17 & 286 & RN 1b & 12900 & 8.11 & 30 \\
RN 5b & 84800 & 7.32 & 591 & RN 6b & 3200 & 8.28 & 42 \\
RN 7b & 1100 & 7.33 & 27 & RN 2b & $\mathbf{1 6 4 4 0 0}$ & $\mathbf{8 . 5 2}$ & $\mathbf{7 4}$ \\
RN 1b & 12900 & 8.11 & 30 & RN 3b & 300 & 7.13 & 110 \\
RN 6b & 3200 & 8.28 & 42 & RN 4b & 900 & 7.17 & 286 \\
RN 2b & $\mathbf{1 6 4 4 0 0}$ & $\mathbf{8 . 2}$ & $\mathbf{7 4}$ & RN 5b & 84800 & 7.32 & 591 \\
RN 8s & 700 & 9.03 & 12593 & RN 3s & 649500 & 9.7 & 2429 \\
RN 2s & 2900 & 9.06 & 3467 & RN 4s & 1059 & 9.37 & 2798 \\
RN 4s & 1059 & 9.37 & 2798 & RN 1s & $\mathbf{1 5 0 2 0 0}$ & $\mathbf{9 . 4 1}$ & $\mathbf{2 8 5 8}$ \\
RN 5s & $\mathbf{4 2 3 4 0 0}$ & $\mathbf{9 . 4}$ & $\mathbf{7 1 5 6}$ & RN 2s & 2900 & 9.06 & 3467 \\
RN 1s & $\mathbf{1 5 0 2 0}$ & $\mathbf{9 . 4 1}$ & $\mathbf{2 8 5 8}$ & RN 5s & $\mathbf{4 2 3 4 0 0}$ & $\mathbf{9 . 4}$ & $\mathbf{7 1 5 6}$ \\
RN 6s & $\mathbf{5 9 1 4 6 0 0}$ & $\mathbf{9 . 4 1}$ & $\mathbf{1 1 5 0 0}$ & RN 7s & $\mathbf{1 5 9 4 0 0}$ & $\mathbf{9 . 5 1}$ & $\mathbf{8 5 7 2}$ \\
RN 7s & $\mathbf{1 5 9 4 0 0}$ & $\mathbf{9 . 5 1}$ & $\mathbf{8 5 7 2}$ & RN 6s & $\mathbf{5 9 1 4 6 0 0}$ & $\mathbf{9 . 4 1}$ & $\mathbf{1 1 5 0 0}$ \\
RN 3s & $\mathbf{6 4 9 5 0 0}$ & $\mathbf{9 . 7}$ & $\mathbf{2 4 2 9}$ & RN 8s & 700 & 9.03 & 12593 \\
\hline
\end{tabular}

TABLE $\mathrm{X}$

Pigments in phytoplankton (chlorophyll $a$ and pheophytin), pH and EC. Bold characters: samples with $\mathbf{p H}>9$. The data are ordered by the sum of the chlorophyll $a+$ pheophytin values.

\begin{tabular}{c|c|c|c|c|c}
\hline \multirow{2}{*}{ Lake } & Chl $a$ & Pheo & Chl $a+$ pheo & \multirow{2}{*}{ pH } & $\begin{array}{c}\text { EC } \\
\text { ng... }\end{array}$ \\
\cline { 2 - 4 } RN 4b & 4.44 & 4.37 & 8.81 & 7.17 & 286 \\
\hline RN 3b & 2.22 & 6.59 & 8.81 & 7.13 & 110 \\
\hline RN 2b & 10.36 & 2.07 & 12.43 & 8.52 & 74 \\
\hline RN 7b & 14.06 & 7.44 & 21.50 & 7.33 & 27 \\
\hline RN 7s & $\mathbf{2 1 . 9 0}$ & $\mathbf{4 . 2 0}$ & $\mathbf{2 6 . 1 0}$ & $\mathbf{9 . 5 1}$ & $\mathbf{8 5 7 2}$ \\
\hline RN 1b & 23.68 & 7.4 & 31.08 & 8.11 & 30 \\
\hline RN 6b & 18.94 & 15.87 & 34.81 & 8.28 & 42 \\
\hline RN 2s & $\mathbf{2 2 . 2 0}$ & $\mathbf{1 5 . 1 0}$ & $\mathbf{3 7 . 3 0}$ & $\mathbf{9 . 0 6}$ & $\mathbf{3 4 6 7}$ \\
\hline RN 5b & 22.69 & 18.06 & 40.75 & 7.32 & 591 \\
\hline RN 4s & $\mathbf{2 9 . 6 0}$ & $\mathbf{1 8 . 7 5}$ & $\mathbf{4 8 . 3 5}$ & $\mathbf{9 . 3 7}$ & $\mathbf{2 7 9 8}$ \\
\hline RN 8s & $\mathbf{2 9 . 6}$ & $\mathbf{2 8 . 4 2}$ & $\mathbf{5 8 . 0 2}$ & $\mathbf{9 . 0 3}$ & $\mathbf{1 2 5 9 3}$ \\
\hline RN 5s & $\mathbf{5 1 . 0 6}$ & $\mathbf{1 0 . 0 6}$ & $\mathbf{6 1 . 1 2}$ & $\mathbf{9 . 4}$ & $\mathbf{7 1 5 6}$ \\
\hline RN 3s & $\mathbf{2 3 1 . 9}$ & $\mathbf{1 2 3 . 8}$ & $\mathbf{3 5 5 . 7}$ & $\mathbf{9 . 7}$ & $\mathbf{2 4 2 9}$ \\
\hline RN 1s & $\mathbf{2 3 7 . 9}$ & $\mathbf{1 2 0 . 9}$ & $\mathbf{3 5 8 . 8 7}$ & $\mathbf{9 . 4 1}$ & $\mathbf{2 8 5 8}$ \\
\hline RN 6s & $\mathbf{2 8 3 6}$ & $\mathbf{5 5 4 . 1}$ & $\mathbf{3 3 9 0}$ & $\mathbf{9 . 4 1}$ & $\mathbf{1 1 5 0 0}$ \\
\hline
\end{tabular}


TABLE XI

Contents of chlorophyll $a$, pheophytin, pH and EC of the samples collected in July (first sampling) and October 2008 (second sampling). Both tables are ordered by pH. Bold characters: the samples in which the sum of the pigment values is significant.

\begin{tabular}{|c|c|c|c|c|c|c|c|c|c|c|c|}
\hline \multicolumn{6}{|c|}{ First sampling } & \multicolumn{6}{|c|}{ Second sampling } \\
\hline \multirow{2}{*}{ Lakes } & Chl & Pheo & $\mathrm{Chl}+\mathrm{Pheo}$ & \multirow{2}{*}{$\mathrm{pH}$} & $\mathrm{EC}$ & I akes & Chl & Pheo & $\mathrm{Chl}+\mathrm{Pheo}$ & \multirow{2}{*}{$\mathrm{pH}$} & \multirow{2}{*}{$\begin{array}{c}\text { EC } \\
\mu \text { S.cm }^{-1}\end{array}$} \\
\hline & \multicolumn{3}{|c|}{$\mu \mathrm{g} . \mathrm{L}^{-1}$} & & $\mu{\mathrm{S} . \mathrm{cm}^{-1}}^{-1}$ & Läkes & \multicolumn{3}{|c|}{$\mu \mathrm{g} . \mathrm{L}^{-1}$} & & \\
\hline BA31 & 2.1 & 1.8 & 3.9 & 6.5 & 95 & BA37 & 20.2 & 12 & 32.2 & 7.98 & 3940 \\
\hline BA2 & 38.4 & 18.8 & 57.2 & 7.09 & 113 & BA2 & 33.5 & 7.5 & 41 & 8.35 & 161 \\
\hline BA32 & 30.7 & 6.9 & 37.6 & 7.74 & 154 & BA31 & 14.7 & 2.4 & 17.1 & 8.69 & 170 \\
\hline BA3 & 27.9 & 6.3 & 34.2 & 7.77 & 172 & BA3 & 34.9 & 7.4 & 42.3 & 8.77 & 229 \\
\hline BA13 & 3.5 & 2.1 & 5.6 & 8.69 & 785 & BA36 & 2.8 & - & & 9.19 & 2116 \\
\hline BA12A & 1.4 & 2 & 3.4 & 8.71 & 1045 & BA5 & 15.4 & 7.6 & 23 & 9.21 & 4567 \\
\hline BA36 & 6 & 5.2 & 11.2 & 8.89 & 940 & BA35 & 82.3 & 17.8 & 100.1 & 9.45 & 2032 \\
\hline BA12B & 120 & 26.5 & 146.5 & 8.98 & 1160 & BA7 & 51.6 & 19.2 & 70.8 & 9.6 & 5641 \\
\hline BA34 & 162.5 & 34.2 & 196.7 & 9 & 1001 & BA9 & -1 & -1 & -2 & 9.67 & 6607 \\
\hline BA35 & 17.1 & 3.6 & 20.7 & 9.09 & 780 & BA22 & 25.1 & 8.1 & 33.2 & 9.67 & 12870 \\
\hline BA22 & 2594.7 & 530.1 & 3124.8 & 9.25 & $\mathbf{5 3 5 7}$ & BA25 & 18.1 & 6.8 & 24.9 & 9.68 & 2317 \\
\hline BA25 & 19.5 & 4.9 & 24.4 & 9.28 & 710 & BA16 & 2399.4 & 4895.1 & 7294.5 & 9.77 & 8410 \\
\hline BA37 & 23.7 & 3.6 & 27.3 & 9.28 & 1750 & BA21 & 2976 & 956 & 3932 & 9.78 & 16360 \\
\hline BA5 & 27.9 & 8.7 & 36.6 & 9.3 & 3185 & BA26 & 1004.4 & 1812.8 & 2817.2 & 9.85 & 6857 \\
\hline BA7 & 25.1 & 11.5 & 36.6 & 9.31 & 2932 & BA24 & 5003.4 & 2287.8 & 7291.2 & 10.06 & 3976 \\
\hline BA21 & 5761.4 & 1738.2 & 7499.6 & 9.33 & 7188 & & & & & & \\
\hline BA24 & 3325.7 & 873.3 & 4199 & 9.38 & 1591 & & & & & & \\
\hline BA9 & 23 & 6.8 & 29.8 & 9.44 & 4140 & & & & & & \\
\hline BA16 & 17.4 & 7 & 24.4 & 9.46 & 3618 & & & & & & \\
\hline BA14 & 152.5 & 28.5 & 181 & 9.49 & 2517 & & & & & & \\
\hline BA26 & 1735.4 & 471.5 & 2206.9 & 9.5 & 2671 & & & & & & \\
\hline BA33 & 4.2 & 2.2 & 6.4 & 9.52 & 438 & & & & & & \\
\hline
\end{tabular}

with very high levels. In the July sample collection at the beginning of the dry season, there was no correlation between pigment content and $\mathrm{pH}$, indicating that the action of the microorganisms during this period did not significantly influence the $\mathrm{pH}$. For the samples collected in October 2008 at the end of the dry season, the samples with high pigment content corresponded to the highest pHs. The interpretation seems to be clear: the action of the phytoplanktonic organisms to increase the $\mathrm{pH}$ occurs in the dry season, concomitant to the blooms, as observed.

Evaporation, in an environment with a water deficit, will cause intense salinisation in the lakes isolated from phreatic recharge. Most of the lakes (those that remain with fresh water all year round) interact with the phreatic zone and thereby do not suffer an intense salinisation. The diversity of the lakes of Nhecolândia in colouration (in the function of microorganisms), the presence or absence of sand beaches (the high salinity of the salinas hinders the growth of Gramineae), the presence of macrophytes (which do not survive in saline waters) and the lower topographic level of the salinas in relation to the neighbouring baias could be explained by the biogeochemical process presented here.

Chemical analyses of the water sampled in July and October of 2008 revealed negative values of saturation indexes for amorphous silica in all samples from the baias (Fig. 2), which indicates undersaturation of the solutions, and values close to zero for the samples from the salinas, indicating a predominant condition of chemical equilibrium between the dissolved and mineral states. Such conditions favour the formation of amorphous silica, especially during the dry season. The salinas' basal substrate, composed of a framework of 

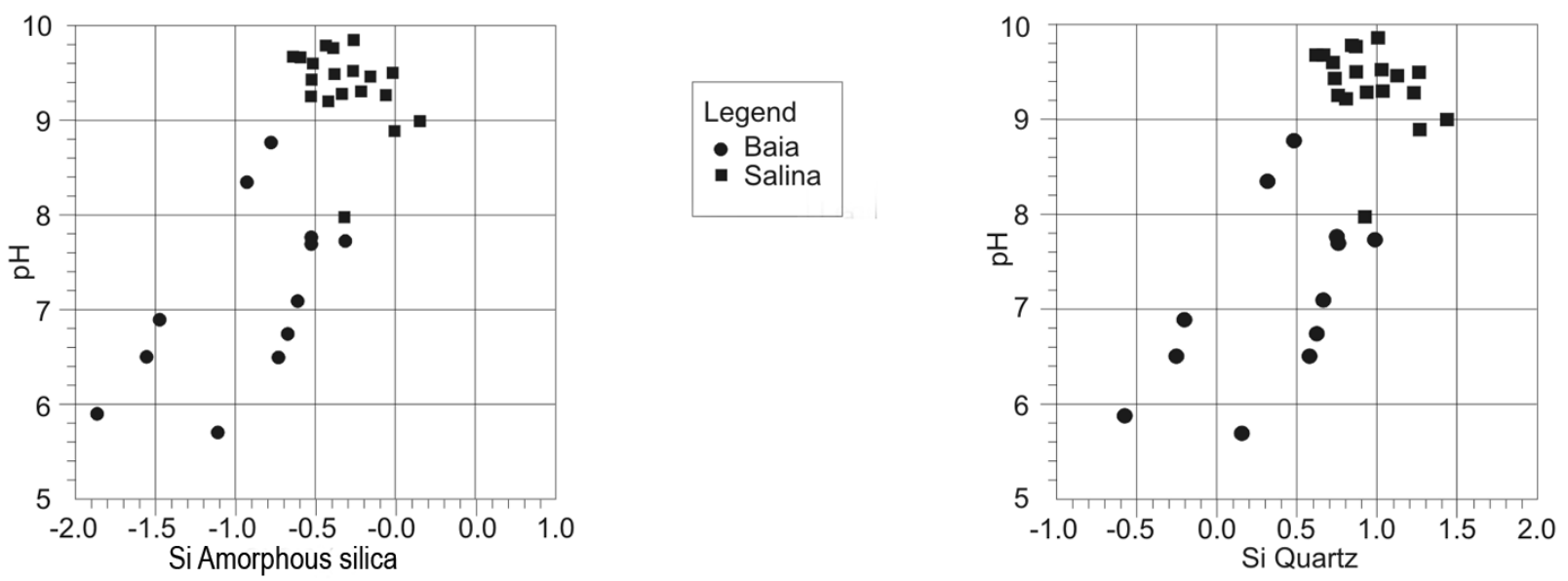

Fig. 2 - Stability of $\mathrm{pH} \times$ amorphous silica (left) and quartz (right) diagram. Modified from Freeze and Cherry's (1971).

quartz sand and a cement of amorphous silica, is extremely impermeable. This promotes hydraulic isolation of the lake from the shallow and locally confined aquifer waters. Figure 2 also indicates that the amorphous silica was in chemical equilibrium with the water samples collected from salinas in July 2008, at the beginning of the dry season. Samples taken in October 2008 (at the end of the dry season) had a higher content of total dissolved solids, but lower concentrations of dissolved silica, as well as relatively lower saturation of amorphous silica, indicating that an removal of silica from the solution to the solid phase, during the monitoring period, probably occurred.

According Freeze and Cherry's (1971) data, the saturation indexes for quartz have positive values (Fig. 2), both for salinas and baias samples (except for three baias samples), indicating that the mineral is mostly not dissolved. This observation is apparently discordant with the hypothesis that the geochemical erosion of quartz in salinas would explain their lower altitudes relative to these from hyposaline lakes, although the quartz dissolution may occur in physicochemical conditions not sampled in the survey, as solutions that precipitate amorphous silica in the sand of the salinas bottom. Furthermore, the adopted model explains the data for all the various types of observations made in the study. These include the relative altitude of the saline and hyposaline lakes, the ratios of stable isotopes of $\mathrm{O}$ and $\mathrm{H}$, the differences in salinity and the origin of the silica in solution and, in images from scanning elec- tron microscopy of the sediments below salinas, amorphous silica in the inter-grain spaces of the sediments under saline-alkaline lakes, corrosion figures at quartz grains and irregular grains surfaces in perfectly adjusted contact to each other. The authors have no alternative model to explain all the data from seven years of research in the region.

\section{CONCLUSION}

This paper presents an original interpretation of the origin of the diversity of Nhecolândia lakes, based on both geochemical and biogenic processes. The poverty in $\mathrm{Ca}^{2+}$ in the regional waters determines an imbalance of the calcium cycle, because this ion is responsible for maintaining the neutral $\mathrm{pH}$ of most surface water on Earth. We propose that this geochemical process was the first to increase the alkalinity of these lakes, according to a shift in the balance in the system $\mathrm{CO}_{2} / \mathrm{HCO}_{3}^{-} / \mathrm{CO}_{3}^{2-}$ to $\mathrm{CO}_{3}^{2-}$ because of the inability to precipitate $\mathrm{CaCO}_{3}$. The phytoplankton, mainly cyanobacteria, help to raise the $\mathrm{pH}$ by consuming inorganic carbon in the form of $\mathrm{CO}_{2}$ and, markedly, $\mathrm{HCO}_{3}^{-}$(which predominates in the solution from $\mathrm{pH}>6$ ), and by excreting $\mathrm{OH}^{-}$.

Originally the water in the lakes should have been fresh, lacking a basis for high salinity. During the evolution of these lakes, the biogeochemical process raised the $\mathrm{pH}$ of the water, facilitating the dissolution of quartzose sand and silt. The silica-rich water (possibly as $\mathrm{H}_{4} \mathrm{SiO}_{4}$ ) penetrated the sediments below the lake bottoms, where amorphous silica was precipitated between 
the clasts. This precipitation could be caused by excessive salinity (during extreme droughts) or drops in $\mathrm{pH}$ (due to contact with the water table). The repetition of this process, including the dissolution of the fraction of amorphous silica precipitated at the surface and of additional amounts of quartz (sand and silt), gradually increases the isolation of the lakes due to the precipitation of amorphous silica, which acts as a cement between the grains of sand, allowing the generation of high-salinity waters. Note that this repeated process will lead to a progressive lowering of the bed of the saline-alkaline lakes. The limit for this lowering may be the groundwater level in extreme drought, which explains the horizontal bottom of the saline-alkaline lakes.

\section{ACKNOWLEDGMENTS}

The authors are grateful to Fundação de Amparo à Pesquisa do Estado de São Paulo (FAPESP - Process 06/ 61052-4) and to Conselho Nacional de Desenvolvimento Científico e Tecnológico (CNPq - Process 483272/ 2007-8) for financing the project. Thanks to the landlords of the Barranco Alto farm, Marina Schweizer and Lucas Leuzinger, for their enormous support and hospitality in the field.

\section{RESUMO}

O Pantanal da Nhecolândia é o maior e mais diversificado campo de lagos da região tropical do planeta, com cerca de 10.000 lagos de variadas salinidade, $\mathrm{pH}$, alcalinidade, cor, fisiografia e atividade biológica dispostos em uma área de $24.000 \mathrm{~km}^{2}$. Os lagos hipossalinos têm $\mathrm{pH}$ variável, baixa alcalinidade, macrófitas e baixa densidade de fitoplâncton. Os lagos salinos tem $\mathrm{pH}$ acima de 9 ou 10, elevada alcalinidade, alta densidade de fitoplâncton e praias de areia. A causa da diversidade desses lagos é uma questão ainda em aberto que é abordada nesta pesquisa. Propõe-se como principal causa um processo híbrido, geoquímico e biológico, baseado em (1) clima com um déficit hídrico importante e pobreza em $\mathrm{Ca}^{2+}$ na água superficial e do freático e (2) na elevação do $\mathrm{pH}$ durante florações de cianobactérias. Estes dois aspectos desestabilizam a tendência geral de $\mathrm{pH}$ neutro para as águas superficiais da Terra. Este desequilíbrio resulta em aumento do $\mathrm{pH}$ e dissolução da areia quartzosa do fundo dos lagos salino-alcalinos. Durante secas extremas há precipitação de sílica amorfa nos espaços inter-granulares dos sedimentos de fundo destes lagos, aumentando seu isolamento do freático. $\mathrm{O}$ artigo discute este processo biogeoquímico, à luz de dados físico-químicos, químicos, fitoplânctonicos e de altimetria de precisão.

Palavras-chave: Pantanal, lagos alcalinos, lagos salinos, cianobactérias, processos de alcalinização.

\section{REFERENCES}

Almeida FFM. 1945. Geologia do sudoeste Matogrossense. Bol DNPM/DGM 116: 1-118.

Almeida TIR, Paranhos Filho AC, Rocha MM, Souza GF, Sigolo JB AND Bertolo RA. 2009. Um estudo sobre as diferenças de altimetria do nível da água de lagoas salinas e hipossalinas no Pantanal da Nhecolândia: um indicativo de funcionamento do mega sistema lacustre. Geociências 28: 401-415.

Almeida TIR, Sígolo JB, Fernandes E, Queiroz Neto JP, Barbiero L AND SAKAmoto AY. 2003. Proposta de classificação das lagoas da Baixa Nhecolândia-MS com base em sensoriamento remoto e dados de campo. R Bras Geoc 33: 83-90.

Apha - American Public Health Association. 1995. Standard methods for the examination of water and wastewater. Springfield, USA, Byrd Prepress.

Assine ML. 2004. Quaternary of the Pantanal, west-central Brazil. Quatern Int 114: 23-34.

ASSUMPÇÃO M. 1998. Focal mechanisms of small earthquakes in the southeastern Brazilian shield: a test of stress models of the South American plate. Geophys J Int 133: 490-498.

Barbiero L, Queiroz Neto JP, Ciornei G, SAKamoto AY, Capellari B AND Fernandes E. 2002. Geochemistry of water and ground water in the Nhecolândia, Pantanal of Mato Grosso, Brazil: Variability and associated processes. Wetlands 22: 528-540.

BARBIERo L, REZENDE FILHO A, FURQUIM SAC, FURIAN S, SAKamoto AY, Valles V, Graham VRC, Fort M, FERrEIRA RPD AND QUEIROZ NeTO JP. 2008. Soil morphological control on saline and freshwater lake hydrogeochemistry in the Pantanal of Nhecolândia, Brazil. Geoderma 148: 91-106.

Costa MPF And Telmer KH. 2007. Mapping and monitoring lakes in the Brazilian Pantanal wetland using synthetic aperture radar imagery. Aquat Conservat Mar Freshwat Ecosyst 17: 277-288.

De-LAmonicA-Freire EM AND HeCKMAN CW. 1996. The Seasonal succession of biotic communities in wetlands of the tropical wet-and-dry climatic zone: iii. The 
algal communities in the Pantanal of Mato Grosso, Brazil, with a comprehensive list of the known species and revision of two desmid taxa. Int Rev ges Hydrobiol Hydrogr 81: 253-280.

DuckWORTh AW, GRANT WD, JONES BE AND VAN SteEnbergen R. 1996. Phylogenetic diversity of soda lake alkaliphiles. FEMS Microbiology Ecol 19: 181-191.

Esteves FA. 1998. Fundamentos de Limnologia. Rio de Janeiro, Brazil, Interciência.

Freeze A AND Cherry J. 1971. Groundwater. Englewood Cliffs, USA, Prentice Hall.

Furquim SAC, Graham RC, BARbiero L, QueIroz Neto JP AND VALlÈs V. 2008. Mineralogy and genesis of smectites in an alkaline-saline environment of Pantanal wetland, Brazil. Clays Clay Miner 56: 580-596.

Furquim SAC, GRAHAM R, BARBIERo L, QUEIROZ Neto JP AND Vidal-TorRado P. 2010. Soil mineral genesis and distribution in a saline lake landscape of the Pantanal wetland, Brazil. Geoderma 154: 518-528.

Galvão LS, Pereira Filho W, Abdon MM, Novo EMLM, SILVA JSVE AND PONZONI FJ. 2003. Spectral reflectance characterization of shallow lakes from the Brazilian Pantanal wetlands with field and airborne hyperspectral data. Int J Remote Sens 24: 4093-4112.

Jones BE, Grant WD, DuckWorth AW AND OWEnSON GG. 1998. Microbial diversity in soda lakes. Extremophiles 2: 191-200.

Kupriyanova E, Villarejo A, Markelova A, GeraSIMENKo L, ZAVARZIN G, SAMUElsSon G, LOS DA AND PRonina N. 2007. Extracellular carbonic anhydrases of the stromatolite-forming cyanobacterium Microcoleus chthonoplastes. Microbiology 153: 1149-1156.

McConnaughey TA AND Whelan J F. 1997. Calcification generates protons for nutrient and bicarbonate uptake. Earth-Sci Rev 42: 95-117.

McCullough JD AND JaCKSOn DW. 1985. Composition and productivity of the benthic macroinvertebrate community of a subtropical reservoir. Int Rev Ges Hydrobiol Hydrogr 70: 221-235.

MEdinA-JÚNior PB ANd RIETZELER AC. 2005. Limnological study of a Pantanal saline lake. Braz J Bio 65: 651-659.

Melack JM And Kilham P. 1974. Photosynthetic rates of phytoplankton in East African alkaline, saline lakes. Limnol Oceanogr 19: 743-755.

Nush EA. 1980. Comparisons of different methods for chlorophyll and phaepigment. Arch Hydrobiol 14: 14-36.

OdUOR SO AND SCHAGERL M. 2007. Temporal trends of ion contents and nutrients in three Kenyan Rift Valley saline-alkaline lakes and their influence on phytoplankton biomass. Hydrobiologia 584: 59-68.

Oliveira MD AND CAlHeiros DF. 2000. Flood pulse influence on phytoplankton communities of the south Pantanal floodplain, Brazil. Hydrobiologia 427: 101-112.

POR FD. 1995. The Pantanal of Mato Grosso (Brazil). World's Largest Wetlands. London, UK, Kluwer Academic Publisher.

SAntos KRS, SAKAmoto AY, Neto MJ, Barbiero L AND Queiroz Neto JP. 2004. Ficoflora do Pantanal da Nhecolândia, MS, Brasil: um levantamento preliminar em três lagoas alcalinas e uma salitrada. In: SIMPÓSIO SOBre Recursos Naturais e Sócio-ECONÔMicos do PANTANAL, 4, Corumbá, Brazil. Proceedings... Brasília: EMBRAPA, 2004, CD ROM.

SANTOS KRS AND SANT'ANNA CL. 2010. Cianobactérias de diferentes tipos de lagoas ("salina", "salitrada" e "baía") representativas do Pantanal da Nhecolândia, MS, Brasil. Rev Bras Bot 33: 61-83.

Sergeev VN, Gerasimenko LM and Zavarzin GA. 2002. The Proterozoic history and present state of cyanobacteria. Microbiologia 71: 623-637.

SHAPIRO J. 1990. Currents beliefs regarding dominance by blue-greens: the case of the importance of $\mathrm{CO}_{2}$ and $\mathrm{pH}$. Verh Internat Verein Theor Angew Limnol 24: 38-54.

SILVA JSV, ABdon MM, Boock A ANd SILVA MP. 1998. Delimitation of the Brazilian Pantanal and its sub-regions. Braz J Agric Res 33: 1703-1713.

Silva LHS, Damazio CM And Iespa AAC. 2008. Identificação de Cianobactéricas em Sedimentos da Lagoa Pitanguinha, Estado do Rio de Janeiro, Brasil. Anu Inst Geoc 31: 11-16.

SMith KS, JAKUBZICK C, WhitTAM TS AND FERRY JG. 1999. Carbonic anhydrase is an ancient enzyme widespread in prokaryotes. PNAS 96: 15184-15189.

THOMPSON JB AND FERRIS FG. 1990. Cyanobacterial precipitation of gypsum, calcite, and magnesite from natural alkaline lake water. Geology 18: 995-998.

TILMAN DL. 1977. Resource competition between phytoplanktonic algae: an experimental and theoretical approach. Ecology 58: 338-348.

USSL - United States SAlinity Laboratory. 1954. Diagnosis and improvement of saline and alkali soils. Washington, USA, U.S. Dept Agricult.

Ussami N, Shiraiwa S And Dominguez JML. 1999. Basement reactivation in a sub-Andean foreland flexural bulge: the Pantanal wetland, SW Brazil. Tectonics 18: 25-39. 
UTHERMOHL H. 1958. Zur Vervolkommung der quantitative Phytoplankton-Methodik. Mitteilungen. Internat Verein Limnol 9: 1-38.

Visscher PT, Reid PR, Bebout BM, Hoeft SE, MacINTYRE IG AND THOMPSON JR JA. 1998. Formation of lithified micritic laminae in modern marine stromatolites (Bahamas); the role of sulfur cycling. Am Mineral 83: 1482-1493.
Westall F. 2005. Life on the early earth: a sedimentary view. Science 308: 366-367.

ZAVARZIN GA. 2002. Microbial geochemical calcium cycle. Microbiologia 71: 1-17. 